\title{
Value Chain Approach and Quality Certificate Applied to Agriculture Entities for the Management of Fruit Trees
}

\author{
Pérez Jhon ${ }^{1}$, Pérez Maria Carmen², González Justo², González Marisol 2, * \\ ${ }^{1}$ The Cuban Association of Agricultural and Forestry Technicians, Havana, Cuba \\ ${ }^{2}$ Science, Technology and Innovation Entity Sierra Maestra, Havana, Cuba
}

\section{Email address:}

paasdirector@iift.cu (P. Jhon), mariacp@bionaturasm.cu (P. M. Carmen), jgonzalez@bionaturasm.cu (G. Justo), mgonzalez@bionaturasm.cu (G. Marisol)

${ }^{*}$ Corresponding author

\section{To cite this article:}

Pérez Jhon, Pérez María Carmen, González Justo, González Marisol. Value Chain Approach and Quality Certificate Applied to Agriculture Entities for the Management of Fruit Trees. International Journal of Agricultural Economics. Vol. 4, No. 5, 2019, pp. $233-244$.

doi: $10.11648 /$ j.ijae.20190405.16

Received: August 28, 2019; Accepted: September 18, 2019; Published: September 29, 2019

\begin{abstract}
The value chain in the agricultural sector, has increased exponentially to become an instrument for strengthened local economies. The process of updating the economic and social model, in Cuba, has considered to implement new policies, strategies and management models, in which value chains are inserted in the agri-food sector, reinforcing the municipal food self-sufficiency from the local agricultural perspective. The present article constitutes an exercise of participatory innovation, implementing a value chain management model in the production of seven agricultural entities devoted to fruit growing. The management model was applied considering the technical-productive, organizational, economic, environmental and social dimensions and was supported by the application of six innovations, eight technological improvements and five scientific results were introduced. Impacts exceeded the base line indicators in all dimensions studied in value chains. The management system has contributed to local agricultural development in their municipalities which was benefited by the organizational, social and productive contribution. A Participatory Guarantee System (GSP) to certify agro-ecological productions, was used for the first time in the country which also favored the application of agro-ecological practices with a holistic approach.
\end{abstract}

Keywords: Agricultural Value Chain, Management in Cuban Agriculture, A Participatory Guarantee System, Certified Agro-ecological Productions

\section{Introduction}

Value chains, as an organizational structure, reflects the continuous evolution of the market economy and represents a change in the behavior of management and organizational strategies, [1] and the relationship of actors participating and interacting throughout this process, either on the basis of formal or informal relations. Physical goods flow from the beginning of the production process until they reach consumers and the financial flows, move from the final consumer to the grower [2].

The development of agri-food value chains is widely recognized as an appropriate approach to promote development in rural areas, increasing the commercialization of agricultural products and improving rural livelihoods. [2]
Global agri-food systems are going through a rapid transformation towards higher value products, stricter food safety standards and more accentuated international and vertical integration. [3]

The Cuban agricultural sector needs transformations adapted to its national context, to revert the weaknesses identified in the study carried out by the Cuban Ministry of Agriculture in 2012, to improve state and business management of the sector, where the main needs are the nonexistence of a systemic approach to implement new policies and management with enough efficacy.

Cuba, in the process of updating its economic and social model, proposes a set of transformations to contribute with efficiency and sustainability to the national economy. Among such needs, food security has been declared a national priority since 2008. [4] 
Traditional tools are insufficient, so it would be important to implement new policies, strategies and management that allow stakeholders to function as a system, with higher levels of integration, organization and adaptability from the perspective of the local development and municipal food self-supply, while contributing to local development [5] as a process oriented from the municipality through transforming actions, articulating and mobilizing local potentials.

In the agricultural sector, the transformation towards a sustainable agriculture has a big social content, and is described as the strengthening of agricultural systems and sustainable local, demand, teaching, research, ways of learning and right policies [6].

The need to achieve municipal food self-supply, presupposes a new model of agri-business with greater autonomy of growers and gradual decentralization towards local governments, continue developing the program of municipal food self-supply, relying on Urban, Suburban and Family Agriculture, and the promotion of small food processors at the local level.

In October 2016, the Ministry of Agriculture drew up issues and instructions to organize and implement municipal self-supply of agricultural products, setting $15 \mathrm{Kg}$ of food per capita per month, both for the municipality and provincial scale.

The present paper is an exercise of participatory innovation developed and supported by the application of scientific results, and technologies in the process of implementing a value chain management model, in agricultural entities devoted to fruit trees growing, with the following objectives:

a) Apply and validate the management model with a value chain approach in the selected agricultural entities devoted to fruit growing.

b) Certify agro-ecological products using a Participatory Guarantee System (GSP).

\section{Methodologies}

\subsection{Diagnosis of Agriculture in Fruit Trees Cooperatives}

The beginning of the studies, implied the creation of an experts group made up of international and national institutions, organizations and actors that were mobilized and integrated. Their abilities, advocacy and decision-making skills were key to the development of the work.

Their respective competition coefficients $(\mathrm{K})$ according to refers by [7]; were always higher than 0.90. The Group of Experts had the mission of analyzing documents on the relevance of applying value chains, which could be influential for municipal self-supply and local agri-food development.

After to analyze the diagnosis made, the external and internal context to identify opportunities and threats, as well as the internal conditions existing in the agricultural sector regarding these productions, the strengths and weaknesses in the selected entities were identified, for which a matrix was developed using the SWOT Analysis technique [8].

Furthermore, was designed the indicators that characterize these entities in the technical-productive, organizational, economic, environmental and social dimensions. The integration of the information collected was validated by stakeholders in workshops held in the municipalities with the participation of the Group of Experts, and growers involved. Afterward, a national workshop was held with a representation of Directors of the Ministries of Agriculture and Foreign Trade, to systematize the results of the municipal workshops and identify those common actions for the different municipalities and their compatibility in case of investment needs.

This stage was developed during 2013 and until early 2014. Seven agricultural entities, chosen in three different organizational forms: five (5) of them were credit and services cooperatives (CCS), one, agricultural production cooperative (CPA) and one, basic cooperative production unit (UBPC), all by its acronym in Spanish, located in seven municipalities from seven provinces, were selected. This sample covers the physical, environmental, geo-climatic, productive and socio-economic diversity of the country, in fruit trees, representing the three geographical areas of the island (west, center and east).

\subsection{Preparation and Application of Questionnaires}

A questionnaire, was prepared to explore experiences of stakeholders about the management model on value chains applied in farms and agricultural cooperatives in all municipalities, as a structured technique for the rapid and abundant collection of information [9]. The reliability index of the final preparation of the questionnaire was measured using Cronbach's Alpha.

The questionnaire was applied to a group of 15 individuals with the characteristics established by [10], to validate its relevance and generated an index higher than 0.88 , which is considered highly reliable according to the methodology used.

The questionnaire was applied to 38 people and the answers were analyzed on its trends. The categorization system applied, according to rules set forth by [11], followed the inductive and deductive category development model of [12] for this qualitative content analysis.

The knowledge about results and impacts obtained in seven scenarios selected for the application of value chain approach management system, were validated in a workshop with participation of growers from the selected scenarios, local, provincial and national decision makers, as well as a representation of specialists from scientific institutions that supported the implementation of value chains and representatives of non-governmental organizations. of HIVOS and SDC.

The answers of the questionnaire were evaluated in a content analysis, with the particularity of the objective opinion according to [13] through which the impacts were identified. The original data, taken from the questionnaire responses, were coded into the corresponding registration units with the precise description of the characteristics of the 
content [14] and the subsequent use of the enumeration and rules of count defined by [15].

\subsection{Value Chain Model Selection Definition of the Impacts Case Study}

Based on the results of the previous analysis, one entity was selected in correspondence with the Urban, Suburban and Family Agriculture scenarios to share the base line indicators measured in 2013 with same results after the organizational model applied in 2018.

The impacts by dimensions were validated too. The case study was the Farm "La Ignacita", of the CCS Manolito Domínguez, located in the municipality of San Miguel del Padrón, Havana. The validation was developed from 2017 to 2018.

\subsection{Design of the Participatory Guarantee System in the Fruit Value Chains}

The proposed system to certify agro-ecological production and processing practices at the local level, based on the compliance with the requirements of the national regulation [16], includes recognition through the market, the social articulation, the empowerment of communities, and contribution to local development.

The structure and functions of the GSP were designed up to the level of the People's Council. The procedure was established to certify productions based on the evaluation indicators for the different dimensions studied. One entity was chosen to apply this system and validate its benefits. The entity selected for this study was the one mentioned above: Farm "La Ignacita".

In order to know the results, a questionnaire on the relevance of the application of the Participatory Guarantee System was prepared and applied to 20 individuals as a way to certify locally developed agro-ecological productions.

\section{Results and Discussion}

\subsection{Diagnosis and Definition of the Base Line}

In the seven productive entities devoted to fruit growing, the main strengths identified, were the existence of bearing orchards, established with different species and using certified material, and that the market demand for fruits, either fresh or processed, was high.

The high post-harvest losses as a result of a weak organizational infrastructure and the existence of few processing centers not linked to growers and consumers, were identified within the most significant weaknesses and similar to the results reached by [17]. The lack of inputs and the long distances to the existing processing centers, with a high cost in transportation, and demotivation in many growers to continue developing these productions, were the main threats.

The high scientific knowledge of the research centers linked to the subject and the political will to promote these productions were recognized as opportunities.
Regarding the indicators, at the time of measuring the base line, the initial situation of the entities showed limitations in the five dimensions studied in terms of poor productive results, low use of agro-ecological practices; low application of innovations, high percentage of entities with economic losses, poor participation in local development and the existence of limited productive chains.

The mentality of changes in management and contributions to local development were insufficient, similar to reported by [18]. In Cuba, the successive organizational changes which the sector has been subjected to, have generated instability in the structures, operation and management abilities [19], which is corroborated by the poor results reached at the base line of selected entities.

The results of the lifting of the base lines in relation to gender, showed low female participation in these structures, coinciding with the percentages reported in this regard among agricultural workers worldwide [20]; even when recognized, there are no significant differences in productivity between farmers of both sexes [21], which is why feminization of agriculture is considered a driving force for the sector [22].

The lack of integrality in the use of agro-ecological practices was evidenced and the ones used were scarce, which showed that there was no coherent and enduring agroecological culture, so it was necessary to reinforce it with training actions, which had been also scarce.

The results of the identification of the base lines show obsolescence of some technologies, lack of knowledge and its application to generate new products and higher revenues.

The main predominant species of fruit trees represented in the seven selected agricultural entities were: mango, mammee, guava and papaya.

In the productive technical dimension, it was identified that monocrop predominated and that orchards lacked irrigation, which affected low yields and low registered productivity.

The use of agro-ecological practices was referred to as low, they used both chemical and organic fertilization. Pest control was predominantly performed by handling chemical pesticides, although biological controls were sometimes used.

In the organizational dimension, it was observed that the management model responded entirely to a simple agricultural production chain and only one had a strategic development program. Less than half of the entities under study had links with the research centers and out of them, in only one, respondents said they made innovations. In another entity, even without links with research centers, respondents declared the application of innovations.

In the economic dimension, four agricultural entities operated at a loss and three showed profits. All of them sold their products fresh in wholesale outlets. Annual income per worker ranged from 2,500 pesos to 6,000 pesos. The average annual income of the seven agricultural entities was 3,905 pesos.

In the social dimension, out of 43 workers in total, only 9 were women, which accounts for $20.9 \%$; There were two 
entities in which there was no female participation. The workers reported that in the 2010-2012 period, only nine trainings were received among all entities, (1.2 training per entity). The perception of his contribution to local development was low.

In the environmental dimension, it is reiterated that monocrop predominates in six of the seven agricultural entities.

\subsection{Results of the Questionnaire Application}

The answers to the questionnaire, identified as main results were: increased food production and diversification; job creation; increased income; the use of new technological processes and the cultural enrichment of the communities, the application of agro-ecological practices in agricultural production, conditioning and processing of healthy fruits for consumption.

A fundamental value for the success of the value chain application is social and environmental sustainability for the entities involved, as reports [2] that which coincides with the elements described as main results in the improvement of productive yields and economic returns.

By looking at the questions of the thematic axis operation of the management model with value chain approach, three main aspects are highlighted:

i. Actors with various functions within the project without being direct beneficiaries of the action (local governments, Ministry of Agriculture municipal delegations, agricultural companies, as well as Associations related), who identified themselves as leaders and facilitators of the process of value chain conformation. This reflects the empowerment of the actors defined as leaders, which according to [2] is a guarantee for the success of a value chain model.

ii. Training and technical assistance as a fundamental process and the way in which it was executed, which used the monitoring and systematic evaluation of the project team.

iii. The construction of a participatory proposal in the implementation of value chains in each territory, and motivation, which was identified as a determining process.

As main insufficiencies, it was determined that $15 \%$ of the actors did not identify the essence of the value chain and its interactions, the lack of inputs for the different phases of the chain, and the ignorance of the regulations for the investment process, aspects that they transformed in the course of the execution of the project.

The interactions between the parts of the chain, refers by [23] coinciding with aspects that, although they were well identified by the actors involved in the questionnaire, not in all cases it worked the same way, given that $15 \%$ of the people answered that the value of the interrelations for the value chain is not yet sufficiently understood and the decision makers were mentioned. This is an aspect that has a lot of significance because it can be decisive in advancing the value chain, and has been reported by others [24].
Training is an element very much dealt with in the literature on the conformation of these management models, but [25], says that not providing enough training, is one of the causes of failure in the application of value chains. It is defined that trust and learning are both key elements in the development of value chains and do not arise immediately, but instead lead to a preparation process [2].

The main aspect in the analysis of the questions related to the relevance of the application of the participatory guarantee system, as a way to certify agro-ecological productions developed at the local level, was the recognition of its application by the majority of respondents.

The responses referred to a large number of agroecological practices incorporated into the agricultural production process and in terms of benefit and processing, the culture radiated to growers and involved in value chains, was highlighted. For the second aspect, pasteurization was the process considered most important and it was where the technologies acquired and put into operation had the greatest impact.

The integration of researchers from research centers and academics contributed to improving the knowledge of the growers and legitimizing, before decision makers, the relevance of the proposals, including awareness and training to minimize these gaps and enable good practices and experiences to be disseminated and recognized by the responsible authorities.

As a limitation to the performance of this certification, the lack of inputs and the misunderstanding of some growers and decision-makers of the effectiveness of this productive model, are identified.

The failure of agricultural projects to form a value chain may be associated with technical, social, economic, political, institutional and environmental causes, [25], which have been taken into account in the present study.

The application of encoder analysis to assess impacts, showed concurrences that allowed a level of reliability of $92 \%$, according to [26]. The actors, in the evaluation, catalogued the social indicators in the new conditions of value chain organization, with substantial improvements for the generation of new jobs, many of them for women and improvement of working conditions.

In the environmental dimension, the indicators more significant were production of biologicals and the measures taken to introduce innovations, the use of agro-ecological practices and the acceptance of these productions by the actors involved in the chains, especially consumers. Regarding the results of the analysis for each of the impacts, the impacts of the highest grades were: waste management, informative documents, training, working conditions, agroecological measures, and brands and records, which were analyzed previously.

In the analysis of the management of the value chain, the impacts of integration, infrastructure improvement and contractual relations were evaluated very well, which speaks in favor of this organizational system, corroborating what was stated by $[27,28]$, among others. 
Among the impacts that are mostly identified with better results for local development, were related to: seed production, agro-ecological or organic productions, increases in tax contribution, income, and quality and prices. The latter referred to the increase of new products with added value.

The analysis that characterized each dimension, was linked to the innovations introduced. Innovation does not occur as an isolated event, but within the framework of networks of actors that make it a social process; which favors not only economic growth, but also social progress and that can generate positive impacts, both in the organizations where it is produced, and in the environment in which it develops and which it is nourished from.

Also, organizations can no act alone to achieve results, they must rely more and more, on the strategic resources of the territory in which they are located. The results allow to affirm that development does not only depend on actions at the macroeconomic level, but also includes, essentially, concrete actions in the microeconomic sphere, that is, in productive, labor activity and the management of agricultural entities involved.

The management model implemented strengthens the competitiveness of agricultural entities. It does so, without departing from the fulfillment of the postulated by [29] when he mentioned the dependence of three increasingly closely related factors: the actions carried out within the entity itself, in order to achieve efficiency and quality of its products and services; the actions related to its suppliers and customers, with their increase from the emergence of new relationships; and those aimed at the outputs of productions with better quality, with added value and recognition for consumers, records and marketing dynamics.

It should be noted that the implementation of value chains in themselves, constitutes an innovation of management methods, which is classified as organizational innovation, or as a system approach, referred by [30].

It is assumed that when analyzing the links in the value chain, the technical-productive dimension was essentially reinforced through changes in the management model or other intervention carried out and that they constituted indicators to improve in the base lines of each scenario.

In the development of the value chains of the seven entities, there were seven innovations applied, eight technological improvements were made and four scientific results were introduced.

As it can see, the highest percentage of transformations correspond to technological improvements and innovations, which reaffirms, as a participatory exercise with a high innovation component, feedback with the scientific results that allowed a better performance of the entities under study.

Once a consensus was reached on the actions to be carried out, the process of implementing the investments and the actions for the introduction of scientific-technical results, technological improvements and innovations in the different links of the value chains was developed, as shown in Table 1, that summarizes the actions carried out by item in all entities. This whole stage was developed in the period from 2014 to 2017.

Table 1. Introduction of scientific-technological results and innovations in the value chains.

\begin{tabular}{|c|c|}
\hline Links & Fruit Value Chain \\
\hline \multirow{4}{*}{ Propagation } & Scientific results \\
\hline & Introduction of new species and propagation of certified material. IIFT germplasm collection. \\
\hline & Innovation. \\
\hline & Design and construction of a burner for combustion of rice husk. [31]. IIHLD \\
\hline \multirow{7}{*}{ Agricultural production } & Scientific results. \\
\hline & Introduction of the polycrop technology and associated crops. \\
\hline & Application of new agro-ecological practices. \\
\hline & Use of biological means for pest control. \\
\hline & Technological improvements \\
\hline & Installation of portable sprinkler irrigation systems. \\
\hline & Use of agricultural tools and equipment for cultural attention (pruning shears, handsaw, chainsaws, backpacks and hoes). \\
\hline \multirow{4}{*}{ Harvest and Gathering } & Technological improvements \\
\hline & Acquisition and use of a harvest package. \\
\hline & Acquisition of equipment for harvesting and collection (Tractor, trailer and truck). \\
\hline & Technological improvements \\
\hline \multirow{7}{*}{ Packing and Processing } & Construction of a facility for the packing, processing, transforming and conserving products. \\
\hline & Innovation. \\
\hline & Introduction of technologies for fruit processing (Small industries). \\
\hline & Introduction of good safety practices in industrial processing. (Value/Quality). \\
\hline & Health certification and implementation of the quality management system. \\
\hline & (Value/Quality). \\
\hline & Implementation of management for waste management. \\
\hline \multirow{5}{*}{ Distribution and Marketing. } & Innovation \\
\hline & Brand creation and registration. \\
\hline & Technological improvements \\
\hline & Acquisition of equipment (dispenser, air conditioning equipment and furniture, for the sale of juices and products). \\
\hline & Other process support improvements (transportation). \\
\hline
\end{tabular}


In the propagation link, five of the seven entities of this chain, the application of rice husk charcoal was introduced as a scientific result, for substrate of fruit nurseries, product of the interrelation with the Institute of Horticultural Research Liliana Dimitrova (IIHLD). For this, the burners for combustion of rice husks had to be designed and built, which was an innovation.

Likewise, different certified propagation materials of mango and guava species were introduced, from the Alquízar Outreach Station of the Tropical Fruit Crops Research Institute, with a view to replace areas with cultivars of higher productive potential, which in the future would contribute to guarantee the sustainability of these value chains.

In the link of agricultural production, polycrops technology was introduced in farms where guava, papaya and pineapple cultivars were associated, mainly, which allowed greater use of the area, increased productivity and diversification of production with high use of incomes.

As a scientific result, new agro-ecological practices were introduced such as the application of biological means produced at the Center for Reproduction of Entomophagous and Entomopathogens of the Alquizar Outreach Station supported by the PAAS project.

In the present study period, 210 thousand individuals of the parasite Heterorhabditis, spp., and 12 million liters of Bacillus thuringiensis were produced. This practice allowed reducing the use of chemicals in the 110 hectares benefited in the fruit value chains.

Another agro-ecological practice used in 30 hectares was live barriers, to minimize the impact of insects on the fruit orchards.

The use of these practices is in correspondence with the concept of integral fruit farms, considered efficient and dynamic by the use of resources and assimilation of agroecological practices by the growers, where the association with other crops is a basic premise. These practices include agro-ecological management of pests and biological control agents. [32]

All this constitutes an improvement in the environmental dimension, where it was recognized in the base line, which dominated monocrop in the selected scenarios for the implementation of fruit value chains.

As a technological improvement, the 110 hectares of fruit value chains with portable sprinkler irrigation systems was useful. This allowed increased yields and favored the introduction of the polycrop technology.

Growers were also supported with tools for agricultural operations as pruning, harvesting and application of biological means.

In the harvest and collection link, technological improvements were introduced such as adequate packaging, weighing means, and equipment for harvesting and transporting fruits (trailers, tractors and trucks). This allowed the adoption of good harvesting practices, to maintain the external and intrinsic quality of the fruits for the fresh market, thus avoiding rots associated to mishandling and bruises, ill- treated fruits that do not reach their final destination, as indicated in the Manual of Good Agricultural Practices of [29], which specifies that fruit collection and good agricultural practices must be accomplished.

As a result of technological improvements, yields increased, which led to an increased collection of fruits and the need to contract seasonal manpower during harvest peaks. This situation contributed to partially transforming the social dimension, by providing the value chain with new sources of employment, which will be strengthened in other links in the chain.

A case study of a retail supermarket in the United Kingdom, refers by [33], valued the fruits, from the growers participating in the value chain using good practices based on the HACCP method. For this, the exchange of information and articulation was very important to ensure that all parties had a high level of technical knowledge, regarding product development and food safety. Included in the indicated benefits, technological, quality, financial and commercial improvements.

In the link of packing and processing, lines for washing fruits were introduced as innovation in packing, and a new link to the original production chains, for the processing of fruits, with the acquisition of seven mini-industries composed of equipment for processing, cooking, reprocessing, packaging and sterilizing. This has been associated to technological improvements of the facilities for packing, processing, transformation and conservation of products.

The inclusion of the processing link in the fruit value chains, was the most important and dynamic element of the transformations made, their contributions reflected in several dimensions of the ones studied.

In the environmental dimension, post-harvest losses were eliminated, as well as the promotion of good practices, such as recycling of packaging, hygiene, safety, input management and waste management.

In the social dimension, on the other hand, the insertion of these mini-industries in the dynamics of local development has been stimulated by the promotion of alliances and productive chains as well as cooperation with the business sector and large industries, which reinforces the organizational dimension. New permanent sources of employment were generated.

In this chain, the scenario of the Farm "El Mamey", of the CCS Cruce de la Trocha, in Ciego de Ávila province, is an example of a link with the large fruit processing industry of the Ceballos Agribusiness Enterprise, since in these mini-industries, fruit pulps are processed and marketed during the beginning and the end of the season, and it is linked to the large industry that is currently paralyzed. The rest of the time, the industry produces for municipal selfsupply, contributing to the local development of the Ciego de Ávila municipality.

In the link of the distribution and commercialization of products, the creation and registration of trademarks by the 
Institute of Hygiene, Epidemiology and Microbiology were registered as innovations, for the products processed in each mini-industry, as well as the sanitary registration, which also led to the preparation and training of personnel in order to comply with the requirements established by the regulatory entities.

As technological improvements in this link, there was air conditioning equipment, furniture and dispensers for the sale of fresh juice at selling points in the localities, thus favoring food self-supply and local development.

In the commercial aspect, the promotion of new brands for local and national consumption has been encouraged.

In all entities, fruit processing allowed the diversification of productions with the introduction of new products in terms of quality and presentation. It also allowed greater use of fruits, eliminated post-harvest losses and added value to the final product, all of which reaffirms its transformation towards value chains that meet the requirements set forth by [28].

The transformation of the productive chains towards value chains of the seven agricultural entities selected in the fruit sector, six innovations were made, eight technological improvements and five scientific results were introduced, which led to the fulfillment of the main characteristics identified by [28], to move from a traditional business to a value chain. The scientific results, technology and innovations are of great significance to solve deficit of supply and demand of agricultural products, also referred by [34].

A value chain is being present, when the primary objective is the value/quality of the product; as an orientation a differentiated product is presented; that its organizational structure be interdependent (one link to the other); Its power relationship goes towards meeting the demands of the market through communication, cooperation and coordination and its philosophy is the optimization of the chain [28]. All of the above is true in the value chains of the seven selected fruit entities, as explained above.
A study of value chains in the fruit sector of Valle del Cauca in Colombia, showed that the links between production and commercialization of fresh fruits and fruit pulps, are partially synergistic, but in this case, it is identified that the organization of the chain is driven from the destination, that is, from the marketing link [35].

Regarding the identification of the technological triggers of productive sustainability, the authors of the mentioned study, found the following coincidences: the development of new systems and procedures focused on productive efficiency (organizational innovation), on the understanding of transforming the productive chains towards value chains. It was also identified as a coincidence, the innovation agreed between companies-suppliers and/or associations-suppliers in order to favor the business dynamics of the actors of the chain and the contributions of human talent of the educational institutions of the region with correct profiles to attend the current and future requirements of the productive linkage.

It cannot be ignored that innovation is an economic phenomenon, but it can be said that it is above all a social phenomenon.

\subsection{Results of Impacts in One Case of Value Chain Model}

The model proposed by [36], shows an illustrative diagram of all the activities of the value chain and the values that are generated until reaching the final customer, as well as the feedback of the market profits to each link in the chain, following the concept of [27]. The links can perform the competitive advantage in two ways: optimization and coordination. These links arise from the way in which an activity with value affects or is affected by others, often they are subtle and go unnoticed.

Results between indicators of base line (2013) and indicator resultants (2018), are described in Table 2.

Table 2. Comparison of 2018 results with the base line of the case study.

\begin{tabular}{|c|c|c|c|}
\hline \multirow{2}{*}{ Dimensions } & Indicators & 2013 & 2018 \\
\hline & Fundamental product & Guava & Polycrops \\
\hline \multirow{10}{*}{ Production } & Total annual fruit production $(\mathrm{t})$ & 36 & 160 \\
\hline & Production area (ha) & 7 & 7 \\
\hline & Food production (t/ha). & 5.1 & 21 \\
\hline & Application of agro-ecological practices $(\mathrm{t})$ & & \\
\hline & 1: Agro-ecological practices are not applied, & 2 & 3 \\
\hline & $\begin{array}{l}\text { 2: Some agro-ecological practices are applied, } \\
\text { 3: Many agro-ecological practices are applied }\end{array}$ & & \\
\hline & Area under irrigation (ha) & 0 & 8 \\
\hline & Type of fertilization $(\mathrm{Q}, \mathrm{O})$ & $\mathrm{O}$ & $\mathrm{O}$ \\
\hline & $\begin{array}{l}\text { Method used in pest control (Q: Chemical fertilizers are applied, O: Only organic fertilizers are } \\
\text { applied, Q- O: Chemical and organic fertilizers are applied) }\end{array}$ & MIP & MIP \\
\hline & Average annual productivity of the fruit farm & 6 & 8 \\
\hline \multirow{5}{*}{ Organizational } & $\begin{array}{l}\text { Organizational type of management (CP: The management model that is applied is production chain, } \\
\mathrm{CV} \text { : The management model that is applied is a value chain.) }\end{array}$ & $\mathrm{CP}$ & $\mathrm{CV}$ \\
\hline & Existence of a development program (YES or NO) & NO & YES \\
\hline & Links with research centers (YES or NO) & NO & YES \\
\hline & Applied innovations & & \\
\hline & $\begin{array}{l}\text { 1: No innovations are made, } \\
\text { 2: Some innovations are made, } \\
\text { 3: Innovations are made }\end{array}$ & 2 & 3 \\
\hline
\end{tabular}




\begin{tabular}{|c|c|c|c|}
\hline \multirow{2}{*}{ Dimensions } & Indicators & 2013 & 2018 \\
\hline & Fundamental product & Guava & Polycrops \\
\hline \multirow{5}{*}{ Economic } & Economic results (Loss (L) or Profit (P)) & $\mathrm{P}$ & $\mathrm{P}$ \\
\hline & $\begin{array}{l}\text { Modality of sale (M: The sales of the productions are carried out wholesale, m: Retail sales are made, } \\
\text { Mm: sales are made wholesale and retail) }\end{array}$ & M & $\mathrm{M}, \mathrm{m}$ \\
\hline & $\begin{array}{l}\text { Type of product sold (F: Products are sold fresh; P: Products are sold processed; F, P: Fresh and } \\
\text { processed products are sold) }\end{array}$ & $\mathrm{F}$ & F, P \\
\hline & Average annual income per worker $(\$)$ & 4800 & 19200 \\
\hline & Training received for production processes in 2010-2012 & 2 & 6 \\
\hline \multirow[t]{2}{*}{ Social } & $\begin{array}{l}\text { Contribution to local development (1: There is no contribution to local development. 2: Low } \\
\text { contribution to local development, 3: Mediumly contribution to local development) }\end{array}$ & 1 & 3 \\
\hline & $\begin{array}{l}\text { Number of growers on the farm (H: Number of men working on the farm, M: Number of women } \\
\text { working on the farm) }\end{array}$ & $6(5 \mathrm{H}, 1 \mathrm{M})$ & $20(11 \mathrm{H}, 9 \mathrm{M})$ \\
\hline \multirow{4}{*}{ Environmental } & $\begin{array}{l}\text { Existence of monocrop or polycrops on the farm (M: There is monocrop in the farm. Q: There is } \\
\text { polycrop on the farm) }\end{array}$ & M & $P$ \\
\hline & $\begin{array}{l}\text { Application of soil conservation measures (1: There are no soil conservation measures, } 2 \text { : They carry } \\
\text { out some soil conservation measures, } 3 \text { : They carry out soil conservation measures) }\end{array}$ & 2 & 3 \\
\hline & Waste management of the production process (Yes: Do waste management, NO: Waste is not handled) & YES & YES \\
\hline & Use of renewable energy (Yes or Not) & NO & YES \\
\hline
\end{tabular}

The graphic expression of the value chain applied in this Farm can be seen in Figure 1, which reflects the interactions between the links and the network of actors involved in the supply to the different links.

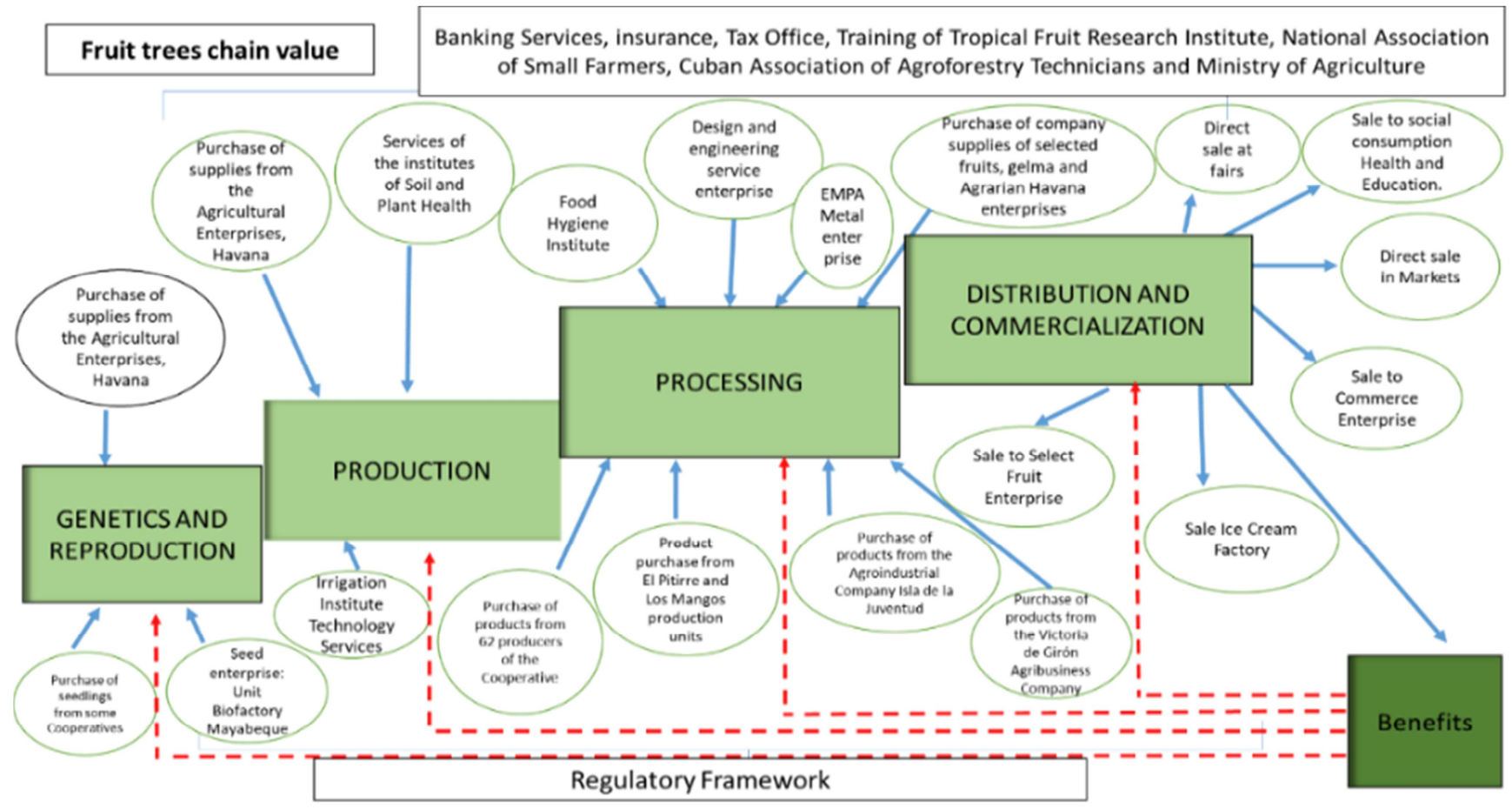

Figure 1. Interactions of the CSC Manolito Dominguez value chain, Farm "La Ignacita".

In the technical-productive dimension of monocrop conditions, it was converted to polycrop, resulting in an increase in the production of $124 \mathrm{t}$, with increases in the yield of $15.9 \mathrm{t} / \mathrm{ha}-1$ and in the annual average productivity of $2 \mathrm{t}$ per worker, even though the quantity of these increased mostly in the industrial process.

In the organizational dimension, the innovation represented by the change to the value chain also led to the development of a program, the improvement of links with scientific institutions, and the application of innovations to the highest category. Of the latter, the introduction of other species that led to the polycrops and especially the installation of irrigation systems stands out, basic premise to achieve crop diversity.

Innovations have had great importance in the rest of the dimensions, it is worth highlighting the incorporation of technologies for fruit processing, which allowed reducing post-harvest losses, generating added value with the diversification of productions, participating directly in the retail market with fresh and processed fruits, and all this managed to increase profits even more. All of this, had as a climax in the economic dimension with a rise of annual salaries by 14400 pesos.

In the case of the social dimension, developing the value chain in this entity, implied the creation of 14 new jobs, out of which $57 \%$ were occupied by women, an important 
contribution to the development of this gender. The training of human resources was also improved by carrying out four new training actions.

The environmental dimension favored polycrop, increased agro-ecological practices, more effective soil conservation measures were applied, and waste management of the miniindustries were used to feed animals.

The contribution of the social dimension to local development, was seen in the increased food availability with better quality than before, generation of jobs with higher salaries and female participation, greater profitability of the entity, which favored contributions to the community for local development, and environmental management with effects to mitigate climate change effect. The construction of the chains was well appreciated as well as the identification of those links that should be strengthened with scientific results, development or innovations to be applied, and training processes required for the assimilation of the technologies and innovations to be introduced.

\subsection{Results of the Participatory Guarantee System in the Fruit Value Chains}

Even when there are advances in agro-ecological agriculture in Cuba, mainly in Urban, Suburban and Family Agriculture, there was no certification system for these productions with the required traceability, from the productive units to local processing facilities.

A proposal for a Participatory Guarantee System (GSP) was designed for the first time in the country to certify agroecological productions, based on international experiences in this participatory certification mechanism, taken in this case to the local level.

In the entity selected to validate the Participatory Guarantee System (GSP), Farm "La Ignacita" of the CCS Manolito Domínguez of the fruit value chain, applied the modeling established from 2015, taking into account the technical-productive, environmental, social and economic dimensions, together with the Group of Local Certifiers, trained for this purpose and were carried out from 2015 to 2017, the corrections required to be able to certify these productions by the system proposed in 2018 .

It is a useful tool to facilitate access to markets and allows to build networks of trust and knowledge between agroecological growers and consumers, a principle assumed by value chains at national and international level [33].

Throughout the process, the Group of Local Certifiers provided support for monitoring and evaluating the process.

Innovations, technological improvements and the introduction of results, carried out in parallel for the transformation of productive chains into value chains, supported the implementation of the Participatory Guarantee System.

In the fruit value chain, guava and polycrops production were certified as main crop, papaya and pineapple were certified. Once the Group of Local Certifiers verified that proposed measures were implemented, the seal and certificate of agro-ecological productions was granted.

The marketing link had a greater social recognition by consumers, being able to verify that these productions were certified with good agro-ecological production practices. In this participatory guarantee system, an increase in prices for this concept was not proposed, but other values promoted by the GSP, were enhanced.



Figure 1. Structure designed for to GSP System. 


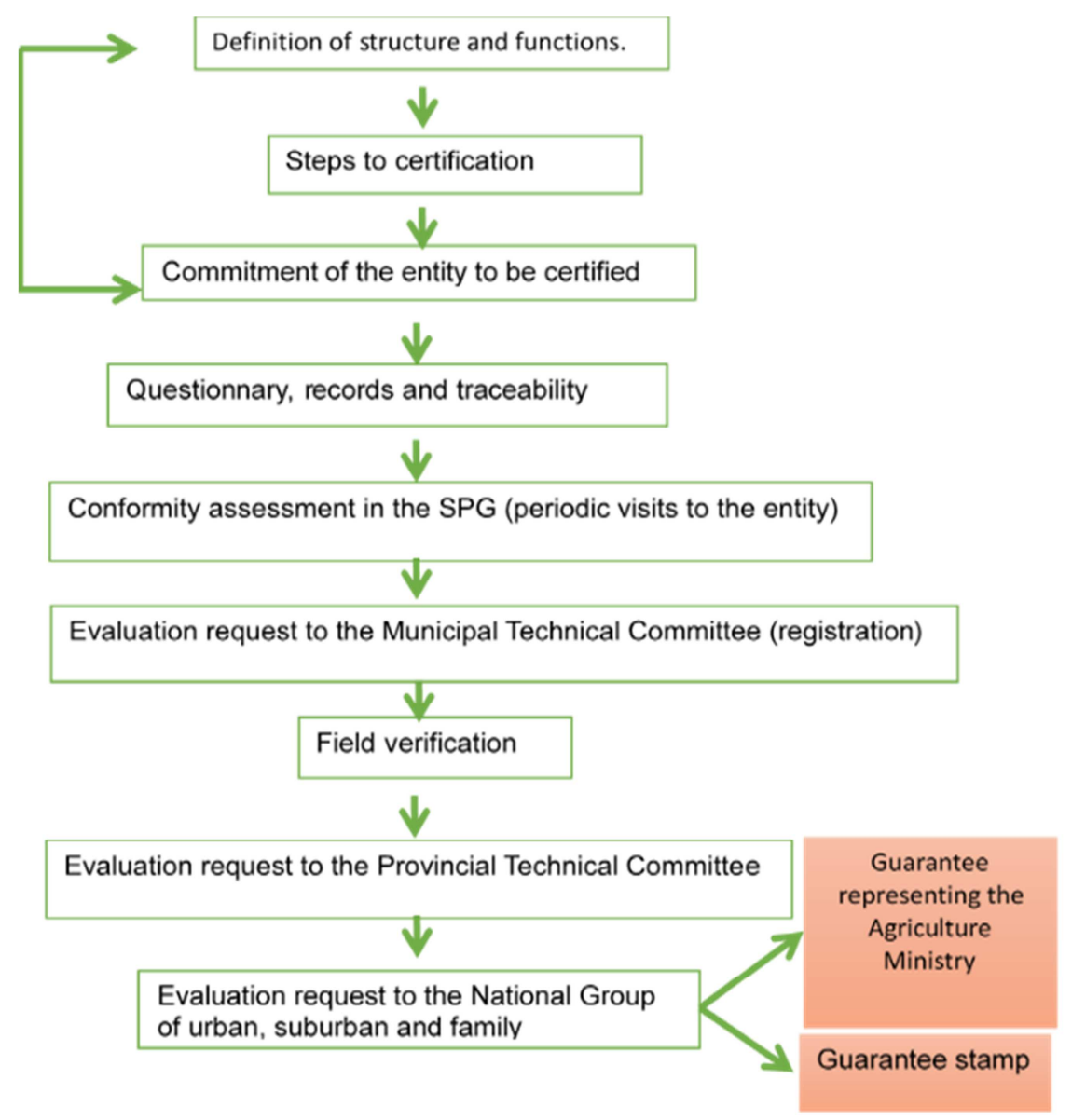

Figure 2. Procedure to achieve the GSP System.

Synergies were carried out with national projects and programs interested in the implementation of the GSP certification methodology such as COBARD, for the implementation of the GSP in protected areas of the biosphere reserve ("Sierra de Rosario" and "Cuchillas del Toa").

In the market studies carried out, the interest of consuming healthier and safer products by institutions of social consumption plus other consumers was true, as well as the interest of supporting municipal, provincial and national authorities, the GSP implementation in the National Urban, Suburban and Family Agriculture Program.

The Participatory Guarantee System Manual summarizes all the research results which 500 copies were printed and distributed among the PAAS Project actors, other growers, local and national decision makers.

As is states by [37] these certification proposals by participatory systems have the strength to respond to territorial consensus processes of the actors involved, they complement each other in that they are based on construction of trust in this type of productions through community organizations and interested persons (growers and consumers respectively).

In this regard, the experiences of this study in the entities where this system was implemented, confirmed that the treatment of trust and guarantee was made as if they were a communal good, whose management corresponded to them as assets similar to that described by [38], in other community contexts in Europe. An example of the system is in figure 2.

Farm "La Ignacita" received the stamp. There was social recognition for good agro-ecological practices, quality offers, and no price increased. This stage of the research corresponded to the 2015-2018 period.

\subsection{Other Contributions}

The local development received the main contributions of innovations in the five dimensions, mainly in the social and environmental branches. More than 200 thousand people are recognized as indirect beneficiaries, for marketed productions.

The training, in addition to being carried out directly to 5,434 people, $44 \%$ women, was enriched with the materials prepared for researches, about the practice experience, that were 10 handbooks and informative books, seven manuals of Good Practices in agro-ecological - organic fruit production; manual on the participatory guarantee system in Cuba; methodological manual on steps of the investment, process in value chains and informative documents on agro-ecological practices.

According to [3], the value chain has become the most used instrument in the analysis of value creation in local economies, which contributes to local economic development. 
This author affirms that, applying this tool locally allows the generation of jobs and income, emphasizing on the grower link; since it is who needs most support, in addition to being the main actor in the struggle against poverty.

This research deals with traits that are shared by [39], among which it can be mentioned the fact that if in the agricultural, fresh and processed products are accepted into this type of chain, it will be necessary to support it with investments; to favor the development of links with scientific centers in productive chains; to help small growers to link to another type of market where retail trade is less concentrated or promote their integration to efficiently introduce them into larger trade; help growers with information on the environmental and social standards of the target markets for their products; develop participatory guarantee systems that allow certifications; develop intelligence actions in these markets; and support the development of increasingly growing innovative capabilities.

\section{Conclusions}

The application of the management model focused on a value chain approach, registered favorable impacts on the technical-productive, organizational, economic, environmental and social dimensions. The application of innovative processes and training of the different actors and decision makers, accompanied by research centers, were fundamental elements of the registered impacts.

The application of a Participatory Guarantee System was demonstrated, for the certification at local level of fruits and vegetable value chains, with an impact on the quality, recognition and elevation of consumer culture, more focused on health and the environment.

Local agricultural development was reinforced with the application of value chain management models in products that contribute to municipal self-supply.

\section{Acknowledgements}

This study was carried out with financial support provided by the Sustainable Agriculture Support Project (PAAS), from 2013 to 2018. The beginning of the PAAS Project was adequate to reaffirm the concepts of agro-ecological production, and creating a certification system for products. We would like to extend our acknowledgement to HIVOS and COSUDE, which supported the study, and the staff of Sierra Maestra Entity of Science and Technology that has greatly supported this study.

\section{References}

[1] L. U. Opara, «Traceability in agriculture and food supply chain: A review of», Food, Agriculture \& Environment, vol. 1, $\mathrm{n}^{\mathrm{o}}$ 1, pp. 101-106, 2003.

[2] D. Neven, Desarrollo de Cadenas de Valor alimentarias sostenibles., 2015.
[3] L. Blanco y Q. Gabith, «Las cadenas de valor como elemento transformador de sistemas de producción local en la Cuenca Guardaña», agosto 2016. [En línea]. Available: https://www.bcb.gob.bo/eeb/sites/default/files/9eeb/archivos/.

[4] R. Castro, «Discurso pronunciado en la Plaza de la Revolución "Ignacio Agramonte" en el Acto Central por el 26 de Julio en Camaguey. Cuba», Granma, 27 julio 2008.

[5] A. Guzón, Desarrollo Local en Cuba. Retos y Perspectivas, Primera ed., La Habana: Academia, 2006.

[6] L. Martín, Desarrollo Local en Cuba. Tecnología y desarrollo agrícola en busca de una nueva coherencia., Primera ed., La Habana: Academia, 2006.

[7] NC 49, Normas Cubanas: Control de la Calidad. Métodos de experto., La Habana, Cuba: Normalización y metrología, 1981.

[8] M. Vasquez Torres y J. Covarrubias, «Planeación estratégica con enfoque de megaplaneación como impulsor de desarrollo agrícola: caso distrito de riego del río mayo 038», Cultura científica y tecnilógica, vol. 11, $\mathrm{n}^{\circ}$ 54, pp. 31-40, 2014.

[9] M. Albert, La investigación educativa. Claves teóricas., Madrid.: Mc Graw Hill, 2007.

[10] S. Aguilar y J. Barroso, «La triangulación de datos como estrategia en la investigación educativa», Revista de medios de educación., pp. 47, 73, 88, 2015.

[11] J. Ruíz, Metodología de la Investigación Cualitativa. Universidad de Deustro. Bilbao., 3ra edición ed., Bilbao: Universidad de Deusto Apartado 1 - 48080, ISBN: 84-7485423-7, 2003.

[12] P. Maryng, «On Generalization in Qualitatively Oriented Research», Forum: Qualitative social research, vol. 8, $n^{\circ} 3, p$. Art 26, 2007.

[13] H. Cantril, The pattern of human concerns, ISBN: 9780813505107 ed., New Jersey: Rutgers University Press, 1966.

[14] O. Holsti, Content analysis for the social sciencies and humanities., ISBN: 978-0201029406 ed., Stanford: Addison Wesley., 1969.

[15] L. Bradin, Análisis de contenido, 2da edición ed., España: AKAL, 1991.

[16] NC 500, Norma Cubana. Directríces para la producción y elaboración de alimentos por métodos orgánicos, La Habana, Cuba: Normalización y metrología, 2010.

[17] H. A. D. Tran Thi Dien, «Developing Orange Fruit Value Chain in Tuyen Quang, Vietnam», Economics, vol. 7, $n^{\circ} 1, p p$. 10-16, 2018.

[18] L. Ledesma y A. Ordaz, «Plan estratégico par la sostenibilidad alimentaria de Mantua. La Universidad en su construcción y gestión», vol. 4, $\mathrm{n}^{\mathrm{o}} 3,2015$.

[19] L. Vasquez, J. Martin y N. Gonzalez, «Políticas públicas y transición hacia la agricultura sostenible sobre bases agroecológicas en Cuba», de Políticas públicas de la agroecología en América Latina y el Caribe, Porto Alegre, Evangraf, 2017, p. 412.

[20] C. Dolan y K. Sorbay, «Gender and employment highly value», Agriculture Rural Development Working, p. 7, 2003. 
[21] S. V. Srinivasan y A. G. Rodrigurez, Perspectivas y desigualdades rurales: Perspectivas de género, juventud y mercado de trabajo, CEPAL: CEPAL. Serie Desarrrollo productivo, 2016.

[22] S. Lastarria, Feminización de la agricultura en América Latina y Africa, Santiago de Chile: RIMISP, 2008.

[23] N. Sablón, A. Acevedo, T. López, J. Acevedo, A. Urquiaga y A Medina, «Análisis de la Cadena Agroalimentaria de Conservas de Tomate Natural en la Provincia Matanzas», Revista Cultivos Tropicales., pp. 124-130, 2015.

[24] H. Deksiso Wari, D. Goshu Habteyesus y A. Kedir Gelato, «Supply and Performance of Wheat Markets in Digelu-Tijo District of», International Journal of Agricultural Economics., vol. 4, n ${ }^{\circ}$ 4, pp. 161-168, 2019.

[25] J. La Gra, «Un primer paso para la disminución de pérdidas de alimentos. Vol. VIII», de Metodología de Evaluación de Cadenas Agroalimentarias para la Identificación de Problemas y Proyectos, San José. Costa Rica., IICA, 2016.

[26] K. Krippendorf, Metodología de análisis de contenido. Teoría y práctica., Primera ed., Barcelona, España: Paidós Comunicación, 1990.

[27] M. Porter, Estrategia Competitiva: Técnicas para el análisis de los sectores industriales y de la competencia., segunda ed., Massachusetts, EEUU: Mc Kinsey and Company, Inc., 1985.

[28] J. Bouma, Value Chains: A Strategic tool for the Canadian agrifood sector, Primera ed., Alberta, Canadá: Toma\&Bouma Management Consultants, 2000.

[29] C. Sánchez, S. González, Z. Acosta y Y. Deus, Manual de buenas prácticas agrícolas para frutas frescas., La Habana: Instituto de Investigaciones de Fruticultura Tropical., 2014.

[30] R. S. Mor, A. Bhardwaj y S. Singh, «A structured literature review of the Supply Chain», de Proceedings of the
International Conference on Industrial Engineering and Operations Management, Indonesia, IEOM Society International, 2018, pp. 588-599.

[31] A. Casanova, Manual para la producción protegida de hortalizas, La Habana: MINAG, 2018.

[32] J. Cueto y L. Otero, Reseña sobre el estado actual de la agroecología en Cuba fruticultura y Agroecología. En avances en la agroecología en Cuba, La Habana.: E. E. Indio Hatuey, 2016.

[33] D. Iglesias, Cadena de valor como estrategias. Las cadenas de valor en el sector agroalimentario., 1ra ed., Non-country specific FAO document: INTA, 2002.

[34] M. Xiaoshuang, «The Road of Urban-Rural Integration Development Under the Rural Revitalization Strategy», International Journal of, vol. 4, $\mathrm{n}^{\mathrm{o}}$ 4, pp. 181-185, 2019.

[35] H. Garzón, Gestión Tecnológica en cadenas productivas frutícolas del Valle. En Ingenieria Industrial, Colombia, 2018.

[36] M. Vinci y A. Hernández, Hacia una Gestión con Enfoque de Cadena. Conceptos Básicos e Instrucciones para el Diagnóstico., 2014.

[37] I. Vara y M. Cuéllar, «Biodiversidad cultivada: Una cuestión de devaluación transmisible», Ecosistema., pp. 1-5, 2013.

[38] J. Castillo y C. Martínez, «La construcción cultural del territorio a través de la actividad agraria», E-rph: Revista electrónica de Patrimonio Histórico, ISSN-e 1988-7213, vol. no procede, $n^{\circ} 17$, pp. 217-221, 2015.

[39] A. García y H. Marquetti, Cadenas, redes y clusters productivos. Aspectos teóricos., La Habana: Centro de Estudios de la Economía Cubana., 2012.

[40] M. Kherallah y M. Camagni, Inclusión sostenible de pequeños productores en cadenas de valor agrícolas. Ampliación de Escalas, 2016. 